\title{
Czech Students' Perceptions of Ethical Behavior in Business and Entrepreneurship
}

http://doi.org/10.21272/bel.4(1).80-91.2020

Dennis Barber III, ORCID: https://orcid.org/0000-0002-3701-5631

$\mathrm{PhD}$, Assistant Professor, Miller School of Entrepreneurship, East Carolina University, USA

John H. Batchelor, ORCID: https://orcid.org/0000-0003-3154-1654

$\mathrm{PhD}$, Associate Professor, Department of Management and MIS, University of West Florida, USA

\section{Timothy Hatten}

$\mathrm{PhD}$, Professor, Department of Business, Colorado Mesa University, USA

Shanan G. Gibson, ORCID: https://orcid.org/0000-0002-2804-9717

$\mathrm{PhD}$, Dean \& Professor, David B. O'Maley College of Business, Embry-Riddle Aeronautical University, USA

Ladislav Rolínek, ORCID: https://orcid.org/0000-0003-2587-8226

$\mathrm{PhD}$, Professor, Department of Economics, University of South Bohemia, Czech Republic

\section{Abstract}

The central notion of business culture and communication with stakeholders consists in the ethical standards regarding the behaviour of corporation owners and managers, which, on the one hand, form an essential element of successful business activities and partnerships, and on the other hand, are complicated in terms of measuring and managing the phenomenon. This study uses agency and stakeholder theories to compare the ethical standards in the behaviour of businessmen and managers. These theories influence freedom of decisionmaking and behaviour in entrepreneurial activity based on the personal ethical considerations and individuals' interests, regardless of the size of their share in the business. The article analyzes data regarding differences in perceptions of business owners and managers by Czech students; the differences between ethical standards of behaviour of Czech and American entrepreneurs and managers; gender peculiarities of Czech students' perception of different business representatives. A methodological tool for the study of ethical perception by youth at the University of the Czech Republic was the Bucar and Hisrich model, and the basis to define the statistical significance of testing the hypothesis - even and odd T-tests. The object of the study contains representatives of small and medium-sized businesses in the Czech Republic, as a country that offers an appealing microcosm for research thanks to the recent transition to a market economy with rapid changes in policy and market activity perceptions. $73 \%$ of respondents previously worked in a small business, almost $44 \%$ had family members who owned or have a small business and $9.5 \%$ owned the business. The sample age structure consisted of $53 \%$ of women and $47 \%$ of men, on average, under 22 years old, $8 \%$ of whom were married. The results of the research revealed that there were no significant differences between the Czech students' ethical perception of managers and businessmen and the lack of influence on the respondents' previous experience in doing business. A study of gender-based sampling revealed that Czech female students are more likely to evaluate entrepreneurs less ethically than men do.

Keywords: Agency Theory, Czech Republic, Entrepreneurs, Ethics, Managers, Stakeholder Theory.

JEL Classifications: M10.

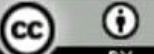

Cite as: Barber III, D., Batchelor, J. H., Hatten, T., Gibson, S. G., Rolínek, L. (2020). Czech Students' Perceptions of Ethical Behavior in Business and Entrepreneurship. Business Ethics and Leadership, 4(1), 80-91. http://doi.org/10.21272/bel.4(1).80-91.2020.

(C) The Authors, 2020. This article is published with open access at Sumy State University.

\section{Introduction}

Ethical perceptions vary from country to country (Ardichvili, Jondle, Kowske, Cornachione, and Thakadipuram, 2012), the ethics of business managers and entrepreneurs are perceived to vary (Batchelor, 
Harris, Gibson, \& Simpson, 2011; Barber III, Ghouse, Batchelor, Chaher, Harris, \& Gibson, 2012; Ghouse, Batchelor, Barber III, Gibson, \& Harris, 2020) and ethical differences do exist between the genders (Bucar \& Hisrich, 2001; Marta, Singhapakdi, \& Kraft, 2008; Smyth, Davis, \& Kroncke, 2009). The Czech Republic is a transition economy which offers a unique opportunity to study the perceptions of entrepreneurs' and managers' ethics. Despite a stagnated economy, entrepreneurship in the Czech Republic has remained stable, with rates of innovation and job creation expectation greater than the global and regional average (Amoros \& Bosma, 2013).

The general public's perceptions of entrepreneurs in post-Soviet economies have been in flux over time. Soon after the transition, especially in the Czech Republic, entrepreneurs were associated more with corrupt politicians and powerful elite than with the working-class citizen trying to make a living, but those perceptions have not been stable. Theory suggests that these perceptions are also subject to gender differences where females are more likely to believe that entrepreneurs are more likely to have control of decision making and therefore behave more ethically. Women played a major role in the post-Soviet transition to market economies by becoming much more active in the workforce and in entrepreneurial activities. The governments in transition economies have notably been slow to address ethical issues especially in business where there was evidence of a high rate of unethical practices. Policymakers have to prioritize during economic transitions due to the many arenas where policy must quickly change with the changing demands of a market economy.

This study empirically tests three categorizations related to ethics using a Czech and U.S. sample of business students including differences between countries, gender differences and differences based on previous exposure to entrepreneurial activities. The study is framed using stakeholder and agency theories, and the differences are tested using a previously validated measure of ethical perceptions (Bucar and Hisrich, 2001). The paper ends with a presentation of future research questions which were motivated by the completion of this study.

\section{Literature Review}

Of the available theories relevant to ethics, we believe that, in the context of comparing business manager vs. entrepreneur, agency and stakeholder theory are the most relevant. Agency theory relates to the relationship between business managers and stockholders (Jensen \& Meckling, 1976; Ross, 1973; Hill \& Jones, 1992). Whereas stakeholder theory argues that the interests of all constituents when decisions are made (Freeman, 1984; Laplume, Sonpar, \& Litz, 2008). As these two perspectives represent somewhat opposing views of how decisions are made and what is considered "ethical" they make for an appropriate backdrop for investigating ethical perceptions individuals hold toward people in the business.

\section{Agency Theory}

The concept of agency centres on the alignment of interest between a principal and agent (Jensen \& Meckling, 1976; Hill \& Jones, 1992). Here, the principal employs the agent to act or perform services on their behalf (Jensen \& Meckling, 1976; Zogning, 2017). These relationships are, generally speaking, complex and ambiguous by nature, especially concerning ethics (Zogning, 2017). Common problematic issues, between the principal and agent, tend to arise when the interests of the principal and agent do not align. An example of such an issue is when the agent acts in his/her own best self-interests (Brock, Shenkar, Shoham, \& Siscovick, 2008; Kim, Prescott, \& Kim, 2005). Thus, divergent self-interests wreak havoc on agency relationships. Thus, principals try to alleviate this issue by aligning the interests of the agent with their interest (i.e. performance pay, stock options, etc.).

The effort exerted in the goal alignment is not free. Such effort manifests itself in the form of agency costs. These are internal governance costs associated with monitoring the behaviour of the agent's actions when acting on behalf of the principal (Chrisman \& Patel, 2012, Jensen \& Meckiling, 1976; Shi, Brian, Connelly, \& Hoskinsson, 2017). The cost of such monitoring is assumed to be more than offset by the potential cost of not monitoring the agent's behaviours, which could result in the agent engaging in behaviour that may be harmful to the principal (Arthurs \& Busentiz, 2003).

Business managers (those employed by others), the agents in the agency discussion up to this point, tend to be given goals by their principals centred on increasing performance (profit, growth, etc.) in one way or another, while "obeying the basic laws and customs of society" (Solymossy \& Masters, 2002: 237). If profit is the goal set for the business manager and their interests are aligned with their principal with a cash payout for reaching certain profit goals and/or benchmarks the agent may place profit ahead of ethics. Here there is a mechanism in place to align and monitor profit goals between the agent and principal, yet no mechanism is in place to 
align and monitor ethical behaviour. This type of lapse in monitoring alignment opens the door for unethical behaviour to go on unnoticed, as it is not being monitored.

When compared to business managers, entrepreneurs are not bound by the same agency relationships. Business managers are employees of another entity that can be hired/fired depending on the wishes of their principal. Entrepreneurs, as self-employed individuals, do not answer to an entity with such control over them. This leads to differing perspectives between business managers and entrepreneurs when it comes to goals such as profit maximization (Bucar, Glass, \& Hisrich, 2003). The ethics of business managers can be restricted by their principal (or upper management acting as the principal) which could prevent them from doing what they perceive to be ethical because of the monitoring mechanism set in place. The ethics of entrepreneurs are not suppressed by such monitoring mechanisms (Humphreys, Robin, Tiedenbach, \& Moak, 1993). Thus these monitoring mechanisms within organizations, be they bureaucratic or otherwise, can hinder the moral development of the decision making abilities of business managers (Solymossy \& Masters, 2002; Weber, 1990; Elm \& Nichols, 1993; Dupont \& Craig, 1996) whereas the moral development of entrepreneurs is not retarded in such way. Thus, for this paper, agency theory can be used to interpret how one might perceive business managers to behave in ways that are less ethical than entrepreneurs because of the pressure they feel to meet performance directives (Cordeiro, 2008), whereas entrepreneurs are free to pursue the goals of their choice (i.e. social entrepreneurs) which may or may not be ethical.

\section{Stakeholder Theory}

Multiple definitions of stakeholder theory exist which leads to many discussions about "what is stakeholder theory" (Miles, 2017). The origins of the theory go back to Freeman (1984) where he postulated that considering the interest of multiple stakeholders could lead to increased performance. Some view stakeholder theory as an alternate view of the firm as compared to stockholder theory which postulates that decisions should be based on what will result in the greatest increase in stockholder wealth (Freeman, 1994; Lamplume, Sonpar, \& Litz, 2008). But, in general, stakeholder theory revolves around the premise that when firms (i.e. business managers within firms) make decisions they should weigh the effect of such decisions on all parties that may be affected (Brenner \& Cochran, 1991). Jensen (2002) goes on to describe affected parties as those that have a "stake" in the organization, thus the name of the theory derives from this concept. Stakeholders are generally grouped into the following typology: customers, employees, suppliers, shareholders, and the community at large (Bucar et al., 2003). While stockholder theory argues that the rights of the stockholders focus on their financial investment in the firm, stakeholder theory argues that the right of stakeholders is intrinsic and does not require such investment to be a concerned party (Hasnas, 1998). Thus, proponents of this theory argue that to be successful an organization must address the needs of all stakeholders, as success is defined by in such terms.

With reference topic at hand, past articles have argued that entrepreneurs are freer to take a stakeholder perspective than are business managers (Batchelor et al., 2011; Barber III et al., 2019; Ghouse et al., 2020). Entrepreneurs are freer to take this perspective because they are not bound by an agency relationship to their principal as are business managers. Thus by having the option of choosing a multiple stakeholder approach to ethics as compared to the constrictions of a profit-maximizing agency relationship that may lead to morally questionable decisions (Solymossy \& Masters, 2002; Weber, 1990; Elm \& Nichols, 1993; Dupont \& Craig, 1996) faced by business managers, entrepreneurs are more free to behave ethically than are business managers.

\section{The Czech Context}

Despite a large amount of economic data on the post-communist transition of Central/Eastern European countries, there is a dearth of research examining the social and demographic changes during the transition (Vecernik, 2002). Demographically, the country saw massive shifts in the fertility rate, divorce rate, and extramarital birth rates. Sobotka, Zeman, and Kantorova (2003) attribute this shift to the changing values, increased emphasis on education, and the emergence of new economic problems experienced by the transitioning Republic. They posit that the transition to a government with democratic values as well as an increased pursuit of higher education has brought the Czech Republic more in line with Western European countries and the demographics associated with them (Sobotka, Zeman, \& Kantorova, 2003; Chase, 1998).

Czech perception of the transition has varied over time, and opinions differ towards the market economy and the political transition. Hraba, Lorenz, Mullick, Lee, \& Vecernik (2001) researched the trends of Czech attitudes towards both the transition to the market economy and the transition to a democratic government. They found that support for the market economy slowly dipped over time from 1990 to 1998. Political support remained stable, although respondents' economic experience was found to be a significant predictor for both economic support and political support (Hraba, Lorenz, Mullick, Lee, \& Vecernik, 2001). 


\section{Entrepreneurship in the Czech Republic}

SME's are becoming an increasingly important facet of the Czech economy. According to the European Commission, SME's account for $54.7 \%$ of total value added to the Czech economy, slightly below the EU average, and $67.2 \%$ of total employment, slightly above the EU average (2018). However, other factors such as total early-stage entrepreneurial activity and established business ownership rate remained below both the regional and global averages. The 2013 report from the Global Entrepreneurship Monitor found that 7.33\% of adults aged 18-64 became either a nascent entrepreneur or owner-manager of a new business (Amoros \& Bosma, 2013). A high concentration of this entrepreneurial activity occurs among the highly educated and those under 35 years of age (Amoros \& Bosma, 2013).

Family businesses have historically been a dominant feature of the Czech economy (Breckova, 2016). However, recent findings have suggested that spin-offs and startups are becoming increasingly popular forms of entrepreneurship in the Czech Republic (Peterkova, Wozniakova, \& Stefanovova, 2014). This influx of innovation has been partially found to be due to an influx of business "incubators" and consulting firms in the region (Peterkova, Wozniakova, \& Stefanovova, 2014). While most SME's in the Czech Republic are in the service industry, the largest SME's industry by value/employment are in manufacturing (Amoros \& Bosma, 2013; European Commission, 2018). A recent influx in manufacturing firms has been attributed to a growing car manufacturing industry in the Czech Republic (European Commission, 2018). While large firms dominate the car industry, Czech SME's have also benefitted from the growing sector (European Commission, 2018). The professional services sector has also grown rapidly in the Czech Republic, with SME employment growing 8\% from 2013-2017 (European Commission, 2018).

The economic transition to a market economy is an important context when examining entrepreneurship in Central and Eastern European countries (Feige, 1994). These transitions are characterized by their rapid policy changes and lagging perception of market activities and play in an important role in creating both entrepreneurship opportunities and barriers (van der Zwan, Verheul, \& Thurik, 2011). These transitions also include a switch to private sectors from public ones, the creation of business intermediaries and support services, and a liberalization of the markets (Smallbone \& Welter, 2001). The speed at which these transitions occur can differ from economy to economy, and the factors involved with the rate of business creation can be complex (Smallbone \& Welter, 2001). Public policy and market reforms have been shown to significantly influence entrepreneurial activity, but strict regulations can also impact informal entrepreneurship (Smallbone \& Welter, 2001).

\section{Perception of Entrepreneurs in the Czech Republic}

There is a notable dearth of research regarding the perception and attitudes towards entrepreneurs in the Czech Republic. The perceptions of entrepreneurs in transition economies can be in flux and change over time. Stephan, Lukes, Dej, and Richter (2008), examined government and public attitudes towards entrepreneurs in several Central and Eastern European countries, namely Poland, the Czech Republic, and East-Germany. It was found that while government perception of entrepreneurs in the Czech Republic remained positive throughout the transition (measured from 1989 to 2002), public perception fluctuated dramatically (Stephan, Lukes, Dej, \& Richter, 2008). While public perception made up 60\% of the positive responses from 19901992, they made up on 32\% from 1995-2002 (Stephan, Lukes, Dej, \& Richter, 2008). This fluctuation was unique to the Czech Republic, as Poland and East-Germany saw a steady increase in positive responses over time (Stephan, Lukes, Dej, \& Richter, 2008).

H1: Czech students will perceive entrepreneurs as less ethical than business managers.

\section{Business Ethics in the Czech Republic}

Despite a wide variety of studies on business ethics during the Czech Republic's transition period, research on modern Czech business ethics is lacking. The transition of the Czech Republic from a planned economy to a market economy presented numerous ethical issues for business practices in the country. Private entrepreneurs and other firms had to reconcile the economic factors present during communist rule with those favoured during the transition and even those present before communist rule (Bohata, 1997). This historical context paved the way for private entrepreneurship to be introduced fairly quickly to the Czech Republic in 1989, however government policy was slow to tackle the ethical issues present in these businesses, despite data suggesting that unethical practices were serious problems in $71 \%$ of Czech companies (Bohata, 1997). It was posited that many of these unethical practices were a result of "new opportunities" presented to businesses, which was supported by industry-specific data in the Czech transitional insurance sector (Bohata, 1997). 
H2: Czech students will perceive entrepreneurs as less ethical than American students will.

H3: Czech students will perceive business managers as less ethical than American students will.

We did not differentiate between Czech entrepreneurs or American entrepreneurs as we gathered the data. Questions were asked about entrepreneurs and business managers in general without country specifics included.

\section{Gender and Entrepreneurship in the Czech Republic}

Recent years have seen the number of women entrepreneurs rise in many regions, and Central Europe is no exception. However, in the Czech Republic, women only made up 39\% of early-stage entrepreneurial activities in 2013, well below the regional average of 56\% and the global average of 66\% (Amoros \& Bosma, 2013). Lituchy \& Reavley (2004) credited women entrepreneurs with contributing to the influx of SME's after the Velvet Revolution in their exploratory study of female entrepreneurship in the Czech Republic and Poland. It was found that women entrepreneurs in these countries displayed very similar characteristics to their North American counterparts (Lituchy \& Reavley, 2004). Interestingly, none of the six women interviewed viewed their gender as a barrier when conducting business, citing government regulation and bureaucracy as the main barrier (Lituchy \& Reavley, 2004). However, without more comprehensive data it is difficult to determine the validity and reliability of these outcomes.

Research in the area of gender perceptions in the U.S. toward managers and entrepreneurs show that female students tend to perceive entrepreneurs to be more ethical than business managers when compared to their male counterparts (Batchelor et al., 2011). Yet another study found there to be little to no difference in these perceptions (i.e. Barber III et al., 2019). Yet the most up to date study in this area (Ghouse, Batchelor, Barber III, Gibson, \& Harris, 2020) found U.S. women to perceive entrepreneurs as more ethical than Omani women. As the ethics gap between genders varies from country to country (Ardichvili, Jondle, Kowske, Cornachione, \& Thakadipuram, 2012) is difficult to make accurate theoretically based predictions about what theses difference may be without empirical testing. Thus, we base the direction of the following two hypotheses on past theory and results:

H4: Women Czech students will perceive business managers as less ethical than women American students will.

H5: Women Czech students will perceive entrepreneurs as less ethical than women American students will.

Regarding gender perception within a country based on the manager/entrepreneur classification scheme, results are mixed (Batchelor et al., 2011; Barber III et al., 2019; Ghouse et al., 2020) but theory points toward females perceiving entrepreneurs as more ethical than their male counterparts. The theory argues that females are more likely to experience more work-family conflict than do males (Williams \& Aglliger, 1994) and that they further perceive entrepreneurs to be more likely and able to alleviate these work-family conflict issues than business managers (Batchelor et al., 2011). Further, Chell, Spence, and Perrini (2016) found that women are more likely to be social entrepreneurs than males. This finding indicates that when rating ethical perceptions, females may be more likely than males to envision a social entrepreneur in their mind when making such a rating than will men. Based on this, we make the following propositions.

H6: Women Czech students will perceive business managers as less ethical than male Czech students will.

H7: Women Czech students will perceive entrepreneurs as less ethical than male Czech students will.

Prior work experience influences attitudes, intentions and perceptions. Full-time work experience increases the ethical behaviours of students (Ruegger and King, 1992; Persons, 2009). Working with small and family businesses leads to a more positive perception of entrepreneurship (Peterman and Kennedy, 2003). This leads us to assume that prior entrepreneurial exposure would lead students to perceive managers and entrepreneurs as making more ethical decisions. Not all studies have found a relationship between exposure and a higher ethical perception of entrepreneurs and managers. Batchelor et al. (2011) found no difference in student perceptions of ethics with previous entrepreneurial exposure when compared to students without exposure. Even so, we make the following hypotheses.

H8: Entrepreneurs will be perceived as more ethical by Czech students with prior entrepreneurial exposure than those without prior business exposure.

H9: Business managers will be perceived as more ethical by Czech students with prior entrepreneurial exposure than those without prior business exposure. 


\section{Methodology}

The ethical perceptions of 73 young adults at a university in the Czech Republic were measured using the Bucar and Hisrich (2001) model. Participants were $47 \%$ male, averaged 22 years of age and only $8 \%$ were married. Seventy-three per cent of respondents had worked for a small business in the past, nearly $44 \%$ had immediate family members that own or had owned a small business and 9.5\% had owned or currently own a small business.

American students were enrolled at two large universities located in the southeast United States. After cleaning the data, there were 116 usable surveys. Student participation was completely voluntary and conducted online. Providing extra credit to the students was left to the discretion of the professor. The participants were $41 \%$ male, $69 \%$ Caucasian and $62 \%$ had prior entrepreneurial exposure through a family-owned business in their immediate family. The average age was 26 years old. A full detailed analysis of this U.S. sample was reported by Batchelor et al. (2011) and this was used for comparison to the Czech data that was collected for the current study. This data is used herein to draw comparisons between business students in the U.S. with business students in the Czech Republic. Therefore, the only new data presented in this manuscript is the data from the Czech Republic, not the U.S. data.

American and Czech students' perceptions of the ethical behaviours of business managers and entrepreneurs were measured using the Bucar and Hisrich (2001) model. The instrument includes five objectives used for its development, which are

1. Maintaining theoretical grounding.

2. Allowing for objective and subjective perspectives.

3. Reflecting the likelihood of actual behaviour in real business situations.

4. Enabling the assessment of potential distortions of responses due to social pressure and

5. Developing a questionnaire that is capable of being replicated in different cultures and economic environments.

These objectives strengthen the tool for use in various cultural settings without losing reliability and validity. The initial testing of the instrument demonstrated consistency with theory. The tool was tested on founders or majority owners and middle to top managers. A larger portion of managers reported they had to sacrifice personal ethics to reach business goals when compared to entrepreneurs. There are 20 behavioural descriptors in the scale and students indicated their degree to which entrepreneurs or business managers would consider these actions as ethical. Responses were given on a five-point Likert scale ranging from "always" to "never". Lower scores on the scale represent higher ethical perceptions. Demographic data on gender, age and marital status were collected along with data on previous exposure to entrepreneurial ventures. The exposure could have been through ownership, familial ownership or working for a firm with less than 25 employees.

\section{Results}

T-tests (paired and unpaired) were used to determine statistical significance for hypothesis testing. After a Shapiro-Wilk test for normality, we failed to reject that the overall measures for the ethical perceptions of managers $(p=0.685)$ and entrepreneurs $(p=0.708)$ were normally distributed, and therefore the $p$-values from the t-tests are powerful enough for hypothesis testing.

The first hypothesis, H1, stated that Czech students will perceive entrepreneurs as less ethical than business managers. Table 1 presents the results for each item in the scale and the measure of overall ethical perceptions. The overall measures were calculated by summing each of the individual items. The results do not show support for H1. There was no overall difference between how students perceived the ethics of managers versus the ethics of entrepreneurs. Only two of the items demonstrated a statistically significant $(p<0.05)$ difference in means. One of those items is a general statement asking students to rank the likelihood that entrepreneurs and managers would "Use a Code of Ethics" in decision making. Even though the overall scores did not produce a significant result, students reported that business managers were statistically significantly $(p<0.05)$ more likely to use a code of ethics when making decisions. A study in the United States (Batchelor et al., 2011), found there was a different perception of managers than entrepreneurs. A study using the same methodology on the perceptions of Omani students found no difference between the ethics of managers and entrepreneurs (Ghouse et al., 2019). 
Table 1.Overall ethical perceptions of Czech students

\begin{tabular}{|c|c|c|c|c|}
\hline & & Entrepreneurs & Business Managers & p-value \\
\hline \multirow{2}{*}{ Overall ethical behaviours score. } & Mean & 42.6301 & 43.0000 & \multirow{2}{*}{0.7269} \\
\hline & SD & 8.6338 & 9.3497 & \\
\hline \multirow{2}{*}{ Use company services for personal use. } & Mean & 2.2602 & 2.2877 & \multirow{2}{*}{0.9169} \\
\hline & SD & 1.8670 & 1.6669 & \\
\hline \multirow{2}{*}{ Remove company supplies for personal use. } & Mean & 1.9726 & 2.0000 & \multirow{2}{*}{0.9068} \\
\hline & SD & 1.4527 & 1.4814 & \\
\hline \multirow{2}{*}{ Overstate expense account by more than $10 \%$. } & Mean & 1.8630 & 2.0548 & \multirow{2}{*}{0.3678} \\
\hline & SD & 1.3262 & 1.6235 & \\
\hline \multirow{2}{*}{ Overstate expense account by less than $10 \%$. } & Mean & 1.863 & 2.0548 & \multirow{2}{*}{0.3678} \\
\hline & SD & 1.3262 & 1.6235 & \\
\hline \multirow{2}{*}{ Use company time for non-company benefits. } & Mean & 1.9315 & 2.1233 & \multirow{2}{*}{0.3465} \\
\hline & SD & 1.4656 & 1.5087 & \\
\hline \multirow{2}{*}{$\begin{array}{l}\text { Give gifts/favours to customers and/or suppliers for } \\
\text { preferential treatment. }\end{array}$} & Mean & 1.9589 & 1.6849 & \multirow{2}{*}{0.2207} \\
\hline & SD & 1.7195 & 1.6987 & \\
\hline \multirow{2}{*}{$\begin{array}{l}\text { Accept gifts/favours from customers and/or suppliers for } \\
\text { preferential treatment. }\end{array}$} & Mean & 2.2054 & 2.3836 & \multirow{2}{*}{0.4498} \\
\hline & SD & 1.6993 & 1.7210 & \\
\hline \multirow{2}{*}{ Blame an innocent employee for errors. } & Mean & 2.0411 & 2.0411 & \multirow{2}{*}{1.0000} \\
\hline & SD & 1.1837 & 1.6367 & \\
\hline \multirow{2}{*}{ Claim credit for another person's work. } & Mean & 1.9315 & 1.6575 & \multirow{2}{*}{0.1326} \\
\hline & SD & 1.2171 & 1.3563 & \\
\hline \multirow{2}{*}{ Someone who calls in sick to take a day off. } & Mean & 2.2740 & 2.1233 & \multirow{2}{*}{0.4749} \\
\hline & SD & 1.2938 & 1.4902 & \\
\hline \multirow{2}{*}{ Employees taking extra personal time. } & Mean & 2.3973 & 2.0959 & \multirow{2}{*}{$0.0402 *$} \\
\hline & SD & 1.1516 & 1.3141 & \\
\hline \multirow{2}{*}{ The use of insider information for personal gain. } & Mean & 1.9315 & 2.1233 & \\
\hline & SD & 1.6611 & 1.8329 & 0.4273 \\
\hline 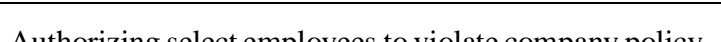 & Mean & 1.9452 & 1.9452 & 10000 \\
\hline Authorizing select employees to violate company policy. & SD & 1.1890 & 1.3833 & 1.0000 \\
\hline Failing to take action for employee violation of company & Mean & 2.2055 & 2.1233 & 06728 \\
\hline policy. & SD & 1.1661 & 1.3328 & 0.0120 \\
\hline & Mean & 2.2054 & 2.0274 & 0.3675 \\
\hline Falsitying reports. & SD & 1.1542 & 1.3741 & $0.50 / 3$ \\
\hline Hiring competitors' emplovees to learn trade cecrets & Mean & 1.8630 & 2.3836 & $0.0763^{1}$ \\
\hline Hirıng competitors employees to learn trade secrets. & SD & 1.4368 & 1.8903 & $0.0 / 05$ \\
\hline Fail to renort emplovee violation of the law & Mean & 2.0548 & 2.1096 & 07496 \\
\hline Fail to report employee violation of the law. & SD & 1.1772 & 1.3183 & 0.1490 \\
\hline Divulas confidential information to outcide parties & Mean & 1.7260 & 2.0000 & $00840^{1}$ \\
\hline Divulge confidential information to outside parties. & SD & 1.0309 & 1.1667 & $0.0840^{2}$ \\
\hline & Mean & 2.0802 & 3.1096 & \\
\hline Use "Code of Ethics" in decision making. & SD & 0.9228 & 0.9510 & $0.0129 *$ \\
\hline Willing to sacrifice personal ethics to achieve business & Mean & 2.9178 & 2.6849 & $00520^{1}$ \\
\hline objectives. & SD & 1.0104 & 1.0913 & 0.0520 \\
\hline
\end{tabular}

Note: ${ }^{*} p<0.05,{ }^{1} p<0.10$

Source: Results from current study

Hypotheses 2 and 3 were related to the potential difference between American and Czech students' perceptions of managers and entrepreneurs. The results did not support the hypotheses that Czech students would perceive entrepreneurs and business managers as less ethical than American students. The results appear in Table 2.

Table 2. Overall ethical perceptions by country

\begin{tabular}{|c|c|c|c|c|}
\hline & & $\begin{array}{c}\text { Czech Republic } \\
(\mathrm{N}=73)\end{array}$ & $\begin{array}{l}\text { United States } \\
\quad(\mathrm{N}=115)\end{array}$ & $p$-value \\
\hline \multirow{2}{*}{ Business Managers } & Mean & 43.000 & 42.8522 & \multirow{2}{*}{0.9424} \\
\hline & SD & 9.3497 & 15.7754 & \\
\hline \multirow{2}{*}{ Entrepreneurs } & Mean & 42.6301 & 39.4174 & \multirow[t]{2}{*}{$0.0716^{1}$} \\
\hline & $\mathrm{SD}$ & 13.4875 & 8.6338 & \\
\hline
\end{tabular}

Note: ${ }^{1} p<0.10$

Source: Results from current study and Batchelor et al. (2011)

Hypotheses 4 through 7 posited that there will be gender differences in the ethical perceptions of students. H4 and $\mathrm{H} 5$ asserted that Czech women would perceive business managers (H4) and entrepreneurs (H5) as less 
ethical than American students would. There was no support found for either of these hypotheses. These results are in Table 3.

Table 3. Overall women ethical perceptions by country

\begin{tabular}{|l|l|c|c|c|}
\hline & & $\begin{array}{c}\text { Czech Republic } \\
(\mathbf{N}=39)\end{array}$ & $\begin{array}{c}\text { United States } \\
(\mathbf{N}=64)\end{array}$ & \multirow{2}{*}{$\boldsymbol{p}$-value } \\
\hline \multirow{2}{*}{ Business Managers } & Mean & 41.4359 & 41.2656 & \multirow{2}{*}{0.9499} \\
\cline { 2 - 4 } & SD & 15.0304 & 9.8000 & \multirow{2}{*}{0.6025} \\
\cline { 2 - 4 } Entrepreneurs & Mean & 41.0254 & 39.6719 & 14.8560 \\
\hline
\end{tabular}

Source: Results from current study and Batchelor et al. (2011)

Hypotheses 6 and 7 stated that women Czech students would perceive business managers (H6) and entrepreneurs (H7) as less ethical than men Czech students will. There was no statistically significant difference between women and men students in the Czech Republic. Business managers and entrepreneurs were not perceived as ethically different according to the overall score. For further investigation, we tested whether there was a difference in the perceptions of women and men students in their responses to the Uses "Code of Ethics" item. There was a statistically significant difference between the genders, but in the opposite direction from $\mathrm{H} 6$ and the same direction as $\mathrm{H} 7$. Women Czech students reported that business managers were more statistically significantly $(p<0.05)$ likely to use a code of ethics when making decisions. Women Czech students reported that entrepreneurs were less likely $(p<0.05)$ to use a code of ethics in decision making. As seen in Tables 4 and 5, there was no support found for $\mathrm{H6}$ and weak support for $\mathrm{H} 7$.

Table 4. Overall ethical perception by gender

\begin{tabular}{|c|c|c|c|c|}
\hline & & $\begin{array}{c}\text { Male } \\
(\mathrm{N}=34)\end{array}$ & $\begin{array}{c}\text { Female } \\
(\mathrm{N}=39)\end{array}$ & $p$-value \\
\hline \multirow{2}{*}{ Business Managers } & Mean & 44.7941 & 41.1359 & \multirow{2}{*}{0.1267} \\
\hline & SD & 9.8000 & 8.5980 & \\
\hline \multirow{2}{*}{ Entrepreneurs } & Mean & 44.4706 & 41.0256 & \multirow{2}{*}{$0.0891^{1}$} \\
\hline & SD & 8.1644 & 8.9078 & \\
\hline
\end{tabular}

Note: ${ }^{1} p<0.10$

Source: Results from current study

Table 5. Uses "Code of Ethics" scores by gender

\begin{tabular}{|c|c|c|c|c|}
\hline & & $\begin{array}{c}\text { Male } \\
(\mathrm{N}=34)\end{array}$ & $\begin{array}{c}\text { Female } \\
(\mathrm{N}=39)\end{array}$ & $p$-value \\
\hline \multirow{2}{*}{ Business Managers } & Mean & 3.3824 & 2.8718 & \multirow{2}{*}{$0.0211 *$} \\
\hline & SD & 0.8639 & 0.9852 & \\
\hline \multirow{2}{*}{ Entrepreneurs } & Mean & 2.5641 & 3.0882 & \multirow{2}{*}{$0.0144 *$} \\
\hline & SD & 0.8824 & 0.9000 & \\
\hline
\end{tabular}

Note: $* p<0.05$

Source: Results from current study

Hypotheses 8 and 9 posited that entrepreneurs (H8) and business managers (H9) will be perceived as more ethical by Czech students with prior business exposure. There was no support for either hypothesis. Table 6 displays the results for the three variants of exposure tested in the study: Previous ownership, immediate family small business ownership and previous work experience in a small business (less than 25 employees). Entrepreneurs and business managers were perceived very similarly regardless of students' previous entrepreneurial exposure.

Table 6. Overall ethical perception scores by exposure

\begin{tabular}{|c|c|c|c|c|c|c|c|}
\hline & & \multicolumn{2}{|c|}{ Ownership } & \multicolumn{2}{|c|}{ Family } & \multicolumn{2}{|c|}{ Work } \\
\hline & & Yes $(N=7)$ & No $(\mathrm{N}=66)$ & Yes $(\mathrm{N}=32)$ & No $(N=41)$ & Yes $(\mathrm{N}=54)$ & No $(\mathrm{N}=19)$ \\
\hline \multirow{3}{*}{$\begin{array}{l}\text { Business } \\
\text { Managers }\end{array}$} & Mean & 40.4286 & 43.2727 & 43.1563 & 42.8781 & 43.4815 & 41.6316 \\
\hline & SD & 10.6279 & 9.2529 & 10.8185 & 8.1615 & 9.3177 & 9.5581 \\
\hline & p-value & \multicolumn{2}{|c|}{0.4480} & \multicolumn{2}{|c|}{0.9007} & \multicolumn{2}{|c|}{0.4621} \\
\hline \multirow{3}{*}{ Entrepreneurs } & Mean & 38.5714 & 43.0606 & 42.0313 & 43.0976 & 42.2778 & 43.6316 \\
\hline & SD & 8.48248 & 8.6003 & 9.8094 & 7.6870 & 8.9851 & 7.6827 \\
\hline & p-value & \multicolumn{2}{|c|}{0.1929} & \multicolumn{2}{|c|}{0.6040} & \multicolumn{2}{|c|}{0.5603} \\
\hline
\end{tabular}

Source: Results from current study 


\section{Conclusion, Discussion and Recommendations}

Overall, there were few differences found in the ethical perceptions of Czech students towards entrepreneurs vs. business managers. Prior entrepreneurial experience also did not seem to influence the ethical perceptions of the Czech business students toward either entrepreneurs or business managers. When it comes to gender, the only effects shown were that female Czech students were slightly more likely to rate entrepreneurs less ethical than male Czech students.

Interestingly, except for slight gender differences, Czech student perceptions are similar to those in the United States. Previous research in India (Barber III et al., 2019) showed substantial differences in the perceptions of Indian and U.S. business students. With the U.S. sample viewing both entrepreneurs and managers as more ethical than their Indian counterparts. Previous research by Chakraborty (1997) and Berger and Herstein (2014) was used to interpret these differences as due to views by those in India of business as being a corrupting force and the negative effects of globalization respectively. Thus, we interpret the similarity between the ethical perceptions of our U.S. and Czech sample to indicate that Czech students do not perceive globalization and the effects of business growth to be corrupting influences in the same way as those in India. This could be due to globalization not having the same negative impact on the Czech Republic as it has on India (see Arora \& Puranki, 2004 for a discussion on globalization and ethics).

In general, except for slight differences between Czech male and female perceptions of business managers, there was little to no difference between the genders in the Czech Republic or between the U.S. and Czech Republic in their ethical perceptions toward entrepreneurs and managers. Ghouse et al (2020) found that female students in the U.S. saw entrepreneurs more ethical than Omani female students. These results were interpreted to be due, in part, to cultural differences (England, 1975) and work-family conflict (Martins, Eddleston, \& Veiga, 2002). Thus, the results of this study show that gender and cultural difference do exist between countries and gender and that further testing is needed at the country level to understand these variations as broad generalizations based on regions are not enough.

This multi-dimensional approach in analyzing perceptions of business manager and entrepreneurial behaviours across countries as dissimilar as the Czech Republic and the U.S. addresses questions with many moving parts. The finding of a few statistically significant differences does not minimize the importance of investigating them. Rather, what this study does is the lay groundwork for further research, including:

1. Are the actual behaviours of business managers and entrepreneurs congruent? There may be more layered factors affecting the behaviours of both groups. Agency and Stakeholder theories are relevant, but future research may find insight by integrating other theories.

2. Do the perceptions of business manager and entrepreneur behaviour align with actual behaviour? Perceptions of behaviour are important. Therefore, a positive finding of this study is that perceptions between our two groups and two countries are very similar. Further research could measure perceptions and compare with actual behaviours of entrepreneurs and managers.

3. Would a larger and more varied sample of countries affect perceptions of entrepreneurial and management ethics? While no statistically significant differences were found between the Czech Republic and U.S ethical perceptions, differences were found when India was in the mix. What could be learned from the addition of more countries in future research?

4. Do perceptions of ethical behaviour of entrepreneurs vary among different generations? This study showed some variation between male and females, but to what extent do ethical behavioural perceptions change or remain constant between Generation Z, Millennials, Generation Y, and Baby Boomers?

5. Does industry type affect the perception of ethical behaviour for entrepreneurs and business managers? Since homogeneity of behavioural expectations cannot be assumed across all industries, further research is needed to test ethical behavioural differences between sectors such as Manufacturing, Service, Finance, Information, Natural Resources, Leisure and Hospitality, and Health Services.

6. What factors influence the ethical perceptions of students? While this study showed that prior entrepreneurial experience did not impact ethical perceptions, are there other factors that would? For example, choice of major, occupation(s) of parents in the household in which students grew up, or the religious background of the student. 


\section{References}

1. Amoros, J., \& Bosma, N. (2013). Global Entrepreneurship Monitor: 2013 Global Report. Babson Park, MA: Global Entrepreneurship Research Association. Available at: https://www.gemconsortium.org/report/gem-2013-global-report.

2. Ardichvili, A., Jondle, D., Kowske, B., Cornachione, E., Li, J., \& Thakadipuram, T. (2012). Ethical cultures in large business organizations in Brazil, Russia, India, and China. Journal of Business Ethics, 104(4), 415428. Available at: https://link.springer.com/article/10.1007/s10551-011-0976-9.

3. Arora, B., \& Puranki, R. (2004). A review of corporate social responsibility. Development, 47(3), 93-100. Available at: https://doi.org/10.1057/palgrave.development.1100057.

4. Arthurs, J.D., \& Busenitz, L.W. (2003). The boundaries and limitations of agency theory and stewardship theory in the venture capitalist/entrepreneur relationship. Entrepreneurship: Theory and Practice, 28(2), 145-162. Available at: https://doi.org/10.1046\%2Fj.1540-6520.2003.00036.x.

5. Barber III, D., Ghouse, S.M., Batchelor, J.H., Chaher, F., Harris, M.L., \& Gibson, S.G. (2019). An investigation of Indian student attitudes towards entrepreneurs and managers. Journal of Entrepreneurship in Emerging Economies, Vol. ahead of print, No. ahead of print. Available at: https://doi.org/10.1108/JEEE09-2018-0091.

6. Batchelor, J.H., Harris, M.L., Gibson, S.G., \& Simpson, L.R. (2011). Students' perceptions of ethical behavior - A comparison of attitudes towards entrepreneurs and traditional business managers. Journal of Applied Management and Entrepreneurship, 16(1), 67-83. Available at: https://search.proquest.com/docview/1415791991?pq-origsite=gscholar.

7. Berger, R., \& Herstein, R. (2014). The evolution of business ethics in India. International Journal of Social Economics, 41(11), 1073-1086. Available at: https://doi.org/10.1108/IJSE-05-2013-0129.

8. Bohata, M. (1997). Business Ethics in Central and Eastern Europe with Special Focus on the Czech Republic. Journal of Business Ethics, 16(14), 1571-1577. Available at: https://doi.org/10.1023/A:1005867132040.

9. Breckova, P. (2016). Family Business in the Czech Republic. European Research Studies, 19(4), 3-15. Available at: https://www.um.edu.mt/library/oar//handle/123456789/29508.

10.Brenner, S.N., \& Cochran, P. (1991). The stakeholder theory of the firm: Implications for business and society theory and research. Paper presented at the annual meeting of the International Association for Business and Society, Sundance, CT. Available at: https://www.pdcnet.org/iabsproc/content/iabsproc_1991_0002_0897_0933.

11.Brock, D.M., Shenkar, Ol, Shoham, A., \& Siscovick, I.C. (2008). National culture and expatriate development. Journal of International Business Studies, 39(8), 1293-1309. Available at: https://doi.org/10.1057/palgrave.jibs.8400361.

12.Bucar, B., \& Hisrich, R. D. (2001). Ethics of Business Managers vs. Entrepreneurs. Journal of Developmental Entrepreneurship, 6(1), 59-82. Available at: https://search.proquest.com/docview/208429118?accountid=10639.

13.Chakraborty, S.K. (1997). Business ethics in India. Journal of Business Ethics, 16, 1529-1538. Available at: https://doi.org/10.1023/A:1005806913385.

14.Chase, R. S. (1998). Markets for communist human capital: Returns to education and experience in the Czech Republic and Slovakia. Industrial and Labor Relations Review, 51(3), 401-423. Available at: https://doi.org/10.1177/001979399805100303.

15.Chrisman, J.J., \& Patel, P.C. (2012). Variations in R\&D investments of family and nonfamily firms: Behavioral agency and myopic loss aversion perspectives. Academy of Management Journal, 55(4), 976997. Available at: https://doi.org/10.5465/amj.2011.0211.

16.Cordeiro, W.P. (2011). Entrepreneurial business ethics: A special case or business as usual? International Journal of Economics and Business Research, 3(3), 241-252. Available at: https://doi.org/10.1504/IJEBR.2011.040018.

17. Dupont, A.M., \& Craig, J.S. (1996). Does management experience change the ethical perceptions of retail professionals: A comparison of the ethical perceptions of current students with those of recent graduates. Journal of Business Ethics, 15(8), 815-826. Available at: https://doi.org/10.1007/BF00381850.

18. Elm, D.R., \& Nichols, D. (1993). An investigation of the moral reasoning of mangers. Journal of Business Ethics, 12(11), 817-833. Available at: https://doi.org/10.1007/BF00871663.

19.England, G. (1975). The manager and his values: An international perspective. Ballinger Publishing Co., Cambridge, MA. Available at: www.jstor.org/stable/2352300.

20.European Commission. (2018). 2018 SBA Fact Sheet - Czech Republic. European Commission. Available at: https://ec.europa.eu/docsroom/documents/32581/attachments/7/translations/en/renditions/native. 
21.Feige, E. (1994). The Transition to a Market Economy in Russia: Property Rights, Mass Privatization, and Stabalization. In G. Alexander, \& G. Skapska, A Fourth Way: Privatization, Property and the Emergence of Market Economies (pp. 57-78). New York: Routledge. Available at: https://ssrn.com/abstract=2793928.

22.Freeman, R.E. (1984). Strategic management: A stakeholder approach. Boston: Pitman. Available at: https://dx.doi.org/10.2139/ssrn.263511.

23.Ghouse, G.H., Batchelor, J.H., Barber III, D., Gibson, S.G., \& Harris, M.L. (2020). American and Omani Student Attitudes towards The Ethics of Entrepreneurs and Managers, Working Paper. Available at: http://smallbusinessinstitute.org/resources/Documents/Proceedings/2020\%20Proceedings.pdf.

24.Hasnas, J. (1998). The normative theories of business ethics: A guide for the perplexed. Business Ethics Quarterly, 8(1), 19-42. Available at: https://doi.org/10.2307/3857520.

25.Hill, C.W., \& Jones, T.M. (1992). Stakeholder-agency theory. Journal of Management Studies, 29(2), 131154. Available at: https://doi.org/10.1111/j.1467-6486.1992.tb00657.x.

26.Hraba, J., Lorenz, F. O., Mullick, R., Lee, S., \& Vecernik, J. (2001). Trends in Czech attitudes toward the market and democracy. Journal of Political and Military Sociology, 29(2), 200-220. Available at: https://search.proquest.com/docview/206654530?accountid=10639.

27.Humphreys, N., Robin, D.P., Reidenbach, R.E., \& Moak, D.L. (1993). The ethical decision-making process of small business owner-managers and their customers. Journal of Small Business Management, 31(3), 922. Available at: https://search.proquest.com/docview/221001027?accountid=10639.

28.Jensen, M.C., \& Meckling, W.F. (1976). Theory of the firm: managerial behavior, agency costs, and ownership structure. Journal of Financial Economics, 3(4), 305-360. Available at: https://doi.org/10.1007/978-94-009-9257-3_8.

29.Kim, B., Prescott, J.E., \& Kim, S.M. (2005). Differentiated governance of foreign subsidiaries in transnational corporations: An agency theory perspective. Journal of International Management, 11(1), 4366. Available at: https://doi.org/10.1016/j.intman.2004.11.004.

30.Laplume, A.O., Sonpar, K., \& Litz, R.A. (2008). Stakeholder theory: Reviewing a theory that moves us. Journal of Management, 34(6), 1152-1189. Available at: https://doi.org/10.1177\%2F0149206308324322.

31.Lituchy, T. R., \& Reavley, M. A. (2004). Women Entrepreneurs: A Comparison of International Small Business Owners in Poland and the Czech Republic. Journal of International Entrepreneurship, 2(1-2), 6187. Available at: https://doi.org/10.1023/B:JIEN.0000026906.28190.df.

32.Martins, L., Eddleston, K.A., \& Veiga, J.F. (2002). Moderators of the relationship between work-family conflict and career satisfaction. Academy of Management Journal, 45(2), 399-409. Available at: https://doi.org/10.5465/3069354.

33.Miles, S. (2017). Stakeholder theory classification: A theoretical and empirical evaluation of definitions. Journal of Business Ethics, 142, 437-459. Available at: https://doi.org/10.1007/s10551-015-2741-y.

34.Persons, O. (2009). Using a corporate code of ethics to access students' ethicality: Implications for business education. Journal of Education for Business, 84(6), 357-366. Available at: https://doi.org/10.3200/JOEB.84.6.357-366.

35.Peterkova, J., Wozniakova, Z., \& Stefanovova, Z. (2014). Innovative Entrepreneurship by Startups and Spin-offs in the Czech Republic. Actual Problems in Economics, 154(4), 247-257. Available at: http://nbuv.gov.ua/UJRN/ape_2014_4_32.

36.Peterman, N.E. and Kennedy, J. (2003). Enterprise education: Influencing student perceptions of entrepreneurship, Entrepreneurship Theory \& Practice, 28(2), 129-144. Available at: https://doi.org/10.1046\%2Fj.1540-6520.2003.00035.x.

37.Ross, S. (1973). The economic theory of agency: the principal problem. American Economic Review, 63(2), 134-139. Available at: www.jstor.org/stable/1817064.

38.Ruegger, D. and King, E.W. (1992). A study of the effect of age and gender upon student business ethics. Journal of Business Ethics, 11(3), 179-186. Available at: https://doi.org/10.1007/BF00871965.

39.Shi, W., Connelly, B.L., \& Sanders, W.G. (2016). Buying bad behavior: Tournament incentives and securities class action lawsuits. Strategic Management Journal, 37(7), 1354-1378. Available at: https://doi.org/10.1002/smj.2400.

40.Smallbone, D., \& Welter, F. (2001). The Distinctiveness of Entrepreneurship in Transition Economies. Small Business Economics, 16(4), 249-262. Available at: https://doi.org/10.1023/A:1011159216578.

41.Sobotka, T., Zeman, K., \& Kantorova, V. (2003). Demographic Shifts in the Czech Republic after 1989: A Second Demographic Transition View. European Journal of Population, 19(3), 249-277. Available at: https://doi.org/10.1023/A:1024913321935.

42.Solymossy, E., \& Masters, J.K. (2002). Ethics through an entrepreneurial lens: Theory and observation. Journal of Business Ethics, 38(3), 227-241. Available at: https://doi.org/10.1023/A:1015832123366. 
43.Stephan, U., Lukes, M., Dej, D., \& Richter, P. G. (2008). Attitudes Towards and Perceptions of Enterpreneurs in Central Eastern Europe (Poland, The Czech Republic, and East-Germany). In G. Zheng, K. Leunk, \& J. Adair, Perspectives and progress in contemporary cross-cultural psychology: Proceedings from the 17th International Congress of the International Association for Cross-Cultural Psychology. https://scholarworks.gvsu.edu/cgi/viewcontent.cgi?article=1123\&context=iaccp_papers.

44.Van der Zwan, P., Verheul, I., \& Thurik, R. (2011). The Entrepreneurial Ladder in Transition and NonTransition Economies. Entrepreneurship Research Journal, 1(2), 2157-5665. Available at: https://doi.org/10.2202/2157-5665.1012.

45.Vecernik, J. (2002). Monitoring the Transition in the Czech Republic: Data, Surveys and Studies. Sociologicky Casopis, 38(3), 365-379. Available at: https://www.jstor.org/stable/41131815.

46.Weber, J. (1990). Managers' moral reasoning: Assessing their responses in three moral dilemmas. Human Relations, 43(7), 687-702. Available at: https://doi.org/10.1177\%2F001872679004300705.

47.Zogning, F. (2017). Agency theory: A critical review. European Journal of Business and Management, 9(2), 18. Available at: https://pdfs.semanticscholar.org/fadd/ed5808bea19359801bae1fbf89c7d917db50.pdf. 